Article

\title{
Professionalizing Pre-Service Biology Teachers' Misconceptions about Learning and the Brain through Conceptual Change
}

\author{
Finja Grospietsch * and Jürgen Mayer \\ Institute for Biology, Biology Education, University of Kassel, Kassel 34119, Germany; jmayer@uni-kassel.de \\ * Correspondence: finja.grospietsch@uni-kassel.de
}

Received: 30 June 2018; Accepted: 6 August 2018; Published: 10 August 2018

check for updates

\begin{abstract}
Scientific concepts of learning and the brain are relevant for biology teachers in two ways: Firstly, the topic is an object of instruction (e.g., long-term potentiation). Secondly, biology teachers must guide their students towards sustainable learning. Consequently, their own understanding of learning and the brain has an especially far-reaching influence on students. Pre-service biology teachers endorse so-called "neuromyths," misconceptions on the subject of learning and the brain (e.g., the existence of learning styles) even though they cover neuroscientific content during their studies. These misconceptions remain relatively stable throughout university education and practical training. In this paper, we transfer the teaching and learning model of conceptual change to the university context. We investigate whether and to what extent a university course developed in accordance with a professional conceptual change model can reduce pre-service biology teachers' endorsement of neuromyths. In a pre-post-design, 57 university students were asked about their professional knowledge, beliefs, neuromyths, and perception and utilization of the university course. We found a positive effect of the intervention on all three elements of students' conceptual understanding. The results show that explicitly refuting misconceptions about learning and the brain (e.g., via conceptual change texts) helps to professionalize neuromyths.
\end{abstract}

Keywords: conceptual change; biology teacher education; pre-service biology teachers; professional knowledge; beliefs; misconceptions; neuromyths; learning; the brain

\section{Introduction}

In the constructivist theory of teaching and learning, learners' preconceptions, their knowledge and beliefs about a given area before receiving instruction, are a central element of the teaching and learning process [1]. With respect to scientific disciplinary knowledge, learners' preconceptions can be either incorrect (= misconceptions [2]) or only appropriate in everyday contexts (= everyday conceptions [3]). In the long run, these preconceptions need to be systematically developed into scientifically appropriate concepts (= scientific concepts). The conceptual change model of teaching and learning is used to effect this transformation in school contexts and has been applied in numerous disciplines, e.g., biology [4-6], history [7], political science [8], and mathematics [9]. Conceptual change research investigates both the process through which learners revise their preconceptions and acquire scientific concepts under conditions of systematic instruction as well as methods of studying and documenting conceptual change and associated challenges [1]. Conceptual change among learners in schools is the subject of numerous further education offerings for teachers. These have shown that even teachers have scientifically inappropriate conceptions and thus must also undergo conceptual change processes as part of their professionalization [10,11]. Consequently, the conceptual change model also has been applied to teacher further education offerings themselves [12-14]. One goal of 
such undertakings is to professionalize in-service teachers' preconceptions, which tend to have formed during their own school years and are thus quite resistant to change [13]. Applying Kunter et al.'s [15] and Shulman's [16] framework, these further education programs seek to build up teachers' content knowledge (CK), pedagogical content knowledge (PCK), and psychological-pedagogical knowledge (PPK) as well as professionalize their beliefs about learning content and instructional practice. Thus far, only a few attempts have been made to integrate the conceptual change model into the university teacher education $[17,18]$, despite the fact that university education is considered a critical juncture for strengthening scientific concepts [19]. This article takes first theoretical and empirical steps in this direction using the example of learning and the brain.

\section{Theoretical Background}

\subsection{Misconceptions about Learning and the Brain}

Biology teachers need to both impart instructional content about learning and the brain and guide their students towards sustainable learning. In contrast to teachers of other subjects, they thus fulfill a dual function: They provide instruction on topics such as the structure and function of the brain and long-term potentiation [20-23] and serve as learning coaches. Therefore, their conceptions about the topic of learning and the brain can thus have even more far-reaching influences on their students' conceptions and learning strategies than those of teachers of other subjects, who "only" guide students towards sustainable learning. Applying Kunter et al.'s [15] and Shulman's [16] framework, biology teachers need CK about curricular content in neuroscience, PPK about the psychology of human learning, and PCK about instructional strategies for sustainable learning. A recent study found that pre-service biology teachers' conceptions of learning and the brain are to a great extent characterized by "neuromyths", even though they complete neuroscientific course content as part of their studies [24]. Neuromyths are "misconception[s] generated by a misunderstanding, a misreading, or a misquoting of facts scientifically established (by brain research) to make a case for use of brain research in education and other contexts" [25] (p. 111). Typically, neuroscientific research results (= kernel of truth) mutate through a series of fallacies and exaggerations into an implication for teaching and learning that is no longer scientifically correct [26]. Examples of this are the existence of learning styles (for which there is no empirical evidence) or the notion that the left and right brain hemispheres generally work autonomously and need to be better linked to one another through coordination exercises (= Brain Gym) [27]. Studies investigating the endorsement of neuromyths among in-service teachers of various subjects have been conducted in the Netherlands, England [27,28], Portugal [29], Greece [30], Switzerland [31], Spain [32], China [33], Turkey [34], Australia [35], Latin America [36,37], the United States [38], and Canada [26]. Howard-Jones et al. [39], Fuentes and Risso [40], Dündar and Gündüz [41], Düvel et al. [42], Canbulat and Kiriktas [43], Kim and Sankey [44], Papadatou-Pastou et al. [45], and Grospietsch and Mayer [24] provide evidence for pre-service teachers' endorsement of neuromyths. Most studies have found that university students believe in a large number of neuromyths, thus indicating a need for intervention. However, no intervention studies have been conducted as of yet. According to Papadatou-Pastou et al. [45], studies should "evaluate changes in prospective teachers' neuroscience literacy and belief in neuromyths after taking courses on neuroscience" (p. 10). Pre-service biology teachers, who receive instruction on neuroscientific content as part of their university studies, have been found to endorse 11 neuromyths: Existence of learning styles, Effectiveness of Brain Gym, Information is stored in specific locations (hard drive), Learning differences due to the use of different hemispheres, Learn best before age 3, Logic in the left hemisphere/creativity in the right, Critical periods of childhood development, Only use 10\% of our brains, Learning while you sleep, Blocked learning is better than interleaved and Genetically-determined number of cells determines learning [24] (Explanations of these neuromyths can be found in that study). All of these neuromyths have concrete implications for learning (e.g., using audio recordings to learn while one sleeps; conducting learning styles tests; setting up early childhood support programs, etc.) They thus not only waste the education 
system's "money, time and effort" [27] (p. 1), but also prevent teachers and learners from spending these resources on more effective theories and methods (e.g., teaching learning strategies). Teaching learning methods in schools that have been demonstrated to be ineffective (e.g., Brain Gym) can also have an effect on students' learning performance and self-efficacy beliefs. Consequently, teachers with accurate knowledge about the functioning of the brain and long-term memory (e.g., that the brain stores information in a network and does not possess specific storage locations) should be better able to dignify and effectively support human learning. Grospietsch and Mayer [24] did not uncover any differences in the endorsement of neuromyths between first-semester students, more advanced students, and post-graduate teacher trainees. Moreover, Grospietsch and Mayer's study [24] demonstrated that neuromyths are misconceptions that exist in parallel to and despite the presence of better scientific concepts. This indicates that even pre-service biology teachers are not able to successfully transform their misconceptions on the topic of learning and the brain into scientific concepts during university teacher education. Thus, while the previous literature on neuromyths has advocated for a greater integration of neuroscience into teacher education [46], this does not seem to be sufficient to professionalize pre-service teachers' misconceptions about learning and the brain.

\subsection{Conceptual Change in Biology Teacher Education}

In the school context, numerous theories of conceptual change exist that vary widely with respect to both terminology and conceptualization [1]. Organization attempts were undertaken by Stark [47], Duit, Treagust, and Widodo [48], and diSessa [49], among others. Stark [47] divided conceptual change theories into cognitive (e.g., framework theory by Vosniadou [50]; the categorization approach by Chi [51]) and situated (e.g., the contextual approach by Caravita and Halldén [52]; the cultural approach by Säljö [53]). In contrast, Duit et al. [48] differentiate between epistemological [54], ontological [55], and affective approaches [56]. DiSessa [49], meanwhile, proposes a hierarchical classification of conceptual change theories according to whether they see misconceptions as coherent entities or disjointed pieces. Applying Kunter et al.'s [15] model of professional competence, in which both professional knowledge [16] and professional beliefs are seen as scientific concepts that ought to be strived for, three conceptual change theories in particular seem suitable for a transfer to the field of teacher education: diSessa's [49] knowledge-in-pieces theory, according to which elements of knowledge must be integrated more strongly with one another, Vosniadou's [50] framework theory approach, which might be used to describe conceptual change from learning biography-based to learning theory-based beliefs, and Chi's [51] categorization approach, which distinguishes among different qualities of misconceptions and recommends specific instructional approaches.

DiSessa's [50] knowledge-in-pieces theory assumes that learners start out in possession of an unstructured knowledge system. What is meant here is a collection of unlinked knowledge components (phenomenological primitives or p-prims for short) that have their origin in scientific reality and/or experiences and interpretations of one's environment. DiSessa [57] sees p-prims as large numbers of small, self-explanatory elements of knowledge that learners have not put in systematic relation to one another, although they do not exist in complete isolation from each other either. P-prims are not arbitrary; they have already proven their worth in helping the learner explain everyday phenomena. The goal cannot be to eliminate or replace them. Instead, they must be linked to other elements of knowledge during the learning process. Consequently, conceptual change refers to the process of combining these knowledge components into a holistic entity. DiSessa [49] terms this a shift from pieces to coherence. A layperson's knowledge structure differs from the scientific concepts of an expert due to its lower level of coherence, or in other words, connections and linkages. Applying this to Kunter et al.'s [15] and Shulman's [16] models of professional knowledge, the three different knowledge areas related to learning and the brain (CK about curricular content in neuroscience, PPK about the psychology of human learning and PCK about instructional strategies for sustainable learning) cannot be linked to a sufficient extent for students to critically engage with neuromyths. Neuromyths are able to remain relatively stable over the course of university teacher education because elements of 
knowledge about learning and the brain from different university courses on neuroscience, pedagogical psychology, and subject didactics remain unlinked. As a result, and following Schnotz [58], pre-service biology teachers must be guided in the direction of greater coherence in order to move beyond a novice's level of knowledge and become learning experts with coherent professional knowledge.

Vosniadou's framework theory approach [50] begins by assuming that learners form what she terms "framework theories" even before instruction begins. Students come to university courses not just with pre-existing knowledge, but also beliefs about the topic of learning and the brain. These are rooted in many years of personal experience (in school and in their private lives), which means that university students can be seen as "blank slates" [59] (p. 4) to an even lesser extent than school students can $[60,61]$. They both have rational and affective beliefs about learning content and instructional practice drawn from their own learning biographies, which are affected by social and situational factors [50]. Applying Kunter et al.'s [15] model of professional competence, initial learning biography-based beliefs must be transformed into professional (i.e., learning theory-based) beliefs. Teachers' beliefs about teaching and learning are key factors in their profession $[60,62]$. Studies show that professionalizing learning theory-based beliefs is not easy and is not successful among all university students [63]. Vosniadou [50] makes it clear that this professionalization can only happen through a slow, gradual process that first leads to the development of synthetic beliefs. Neither learning biography-based nor synthetic beliefs are based on scientific models, but rather beliefs that have long proven useful to the learner. This makes conceptual change particularly difficult. Recategorizations take a long time and are associated with misconceptions, inconsistencies, and fragmentations. In Vosniadou's view, preconceptions are dynamic belief systems that should be drawn upon over a long period of time and in a constructivist way. From the perspective of her framework theory, neuromyths can be seen as deeply-anchored learning biography-based beliefs that are synthetically complemented but not replaced by the learning theory-based beliefs taught at university. One example of learning theory-based beliefs are beliefs about teaching and learning. These beliefs can be differentiated into transmissive beliefs and constructivist ones [64]. Constructivist beliefs about teaching and learning see learning as an active, self-regulated process. A key characteristic of constructivist instruction is providing individual support to learners in their learning process [62]. In contrast, the assumption that knowledge and information can be transferred from a teacher to his or her students forms the core element of transmissive beliefs about teaching and learning [64]. Pre-service teachers with constructivist beliefs about teaching and learning should reject the notion that knowledge can be absorbed and sustainably learned via, e.g., visual input alone, as argued in learning styles theory. Instead, the active, repeated application of learning strategies to organize and refine the learning content should be effective, irrespective of the medium. If the neuromyth that learning styles exist is endorsed despite constructivist beliefs, this might be because teachers who, for example, encounter this concept during their own school careers, at university, or in schoolbooks, find it to be plausible, even though neuroscientists and cognitive psychologists would consider it a neuromyth. Consequently, teachers who have encountered the neuromyth concerning the existence of learning styles during their learning biography may continue to find it accurate and useful even after expanding their learning theory-based beliefs. Multiple, even competing concepts [65] can be endorsed, or synthetic models can be formed that 'peacefully' co-exist in one and the same person [47] (p. 138). The co-existence of misconceptions and scientific concepts among school students is tolerated as long as the scientific concept is applied in scientific settings. Given that teachers have been found to integrate neuromyths into their professional practice (e.g., by conducting learning styles tests [28]), a context-dependent rejection of everyday concepts in favor of scientific concepts in the area of learning and the brain does not seem to exist as of yet. Thus, according to Schnotz [58], teachers must receive greater support in recognizing what concepts are expedient to be applied to which given contexts. Following Schnotz's [58] and Kagan's [66] calls to create more spaces for reinterpreting previous experiences in light of new theoretical propositions, students should be 
given more opportunities to have new experiences with learning theory-based beliefs that outweigh established learning biography-based beliefs.

According to Chi's [51] categorization approach, learners' preconceptions can have differing qualities. Chi differentiates between inaccurate and incommensurate misconceptions. Inaccurate misconceptions can be divided further into false single beliefs and flawed mental models, incommensurate misconceptions into category mistakes and missing schemas. Each type necessitates a different conceptual change path and thus a different form of instruction. Neuromyths-described as false single beliefs-need to be addressed concretely and refuted step-by-step in order to be revised. This is not yet successfully taking place in teacher education, even though refutation treatments have been demonstrated to have positive effects on students' learning gains for other topics [67]. Conceptual change texts are "one of the most successful techniques based on [the] conceptual change approach" [68] (p. 240) and represent a methodological means of refuting false single beliefs [69-71]. Conceptual change texts are a specific type of text in which a false single belief that the reader may have is first explicitly acknowledged before the corresponding scientific concept is explained [72,73]. According to Egbers and Marohn [74], the reader must write a reflection before and after reading the text in which they take a clear position on a given statement (e.g., a neuromyth). These position statements differentiate conceptual change texts from refutational texts [75], which are also constructed as refutations but do not require any additional grappling with one's own conceptions. By working through conceptual change texts, learners are made aware of scientifically incorrect concepts, creating a cognitive conflict that can serve to initiate conceptual change. Egbers and Marohn [74] demonstrate that learners appreciate the repeated, consistent, and credible explanations as well as the affective aspects of these texts. They further emphasize the uniquely interactive nature of these texts, which explicitly address the reader's misconceptions and thus make reference to thoughts he or she may have.

In summary, three conceptual elements for university education can be derived from these theoretical considerations: Firstly, more deeply linking professional knowledge; secondly, creating more space for new personal experiences with learning theory-based beliefs that are weightier than established learning biography-based beliefs; and thirdly, refuting false single beliefs. Thus, we define professional conceptual change as a specific learning process within professional development in which individual elements of knowledge and subjective beliefs based on pre-service teachers' own experiences develop into coherently linked, career-related scientific concepts (professional knowledge and learning theory-based beliefs) and learners' misconceptions are explicitly refuted [76]. The present paper describes a study on whether and to what extent pre-service biology teachers' endorsement of neuromyths can be professionalized via a specific university course in which all three theoretically-posited elements of professional conceptual change are explicitly applied and empirically tested.

\section{Materials and Methods}

\subsection{Research Questions}

The application of the three theoretically-derived conceptual elements of professional conceptual change was evaluated on the basis of three research questions:

1. What levels of professional knowledge (CK, PPK, PCK) and associations among these areas exist before and after students complete the university course?

2. What levels of learning theory-based beliefs exist before and after students complete the university course?

3. What effects do conceptual change texts have on the endorsement of neuromyths in comparison to reflection tasks on one's own learning? 


\subsection{Research Participants}

The research participants were 57 pre-service biology teachers studying at the University of Kassel. The sample was composed of two groups. The intervention group $(n=40)$ completed the university course based on the professional conceptual change model and received nine conceptual change texts as homework (seven on neuromyths and two on scientific concepts). The comparison group $(n=17)$ instead received reflection tasks on their own learning in the course. $76 \%$ of participants in the total sample were female. $64 \%$ of respondents were studying to be academic-track secondary school teachers (Gymnasiallehramt) and 36\% were studying to be teachers in lower-track secondary schools (Lehramt für Haupt- und Realschulen). The topic of learning and the brain is part of the curriculum for both types of schools. They were in their seventh semester of studies on average $(S D=1.83)$ and ranged in age from 20 to 32 years $(M=24, S D=2.72)$.

\subsection{University Course}

The university course entitled "Sustainable Learning" [77,78] was offered for three semesters at the University of Kassel. The comparison group completed the course in the summer semester of 2016 and the intervention group in summer semester 2017 and winter semester 2017/2018. The course contents and learning experiences were equal for all three groups. The timing, amount, and scope of homework assignments were held constant as well (Table 1). The groups only differed in whether they received conceptual change texts (intervention group) or reflection tasks on their own learning (comparison group). Each course lasted 14 weeks. Students could voluntarily elect to participate in the course. Some students chose to have the course be graded $(42 \%)$, and others received a certificate of participation (58\%). Each weekly session lasted $90 \mathrm{~min}$. In addition to 12 content-related sessions, two organizational sessions were held. The following aspects of the topic of learning and the brain were addressed:

- Cognitive psychological foundations: multi-store and multi-process model of memory, learning strategies theory

- Neuroscientific foundations: structure and function of the brain, organization of long-term memory, long-term potentiation

- Foundations related to biology didactics: students' conceptions of brain functioning, instructional strategies for sustainable learning (e.g., self-regulated learning)

Drawing upon the first element of the professional conceptual change model, these contents were conveyed in a connected way through the interleaved teaching of PPK, CK, and PCK (columns 3 and 4 of Table 1).

For example, the first session of the first block addresses the multi-store model of memory from a cognitive psychological perspective (PPK). This is followed in the second session by a neuroscientific focus on the structure and function of the brain (CK). The third block then addresses school students' conceptions about the brain from the perspective of subject didactics (PCK). In the fourth and final session of the first block, these areas of knowledge are linked together and applied to the construction of teaching materials. Following Block and Hazelip [79], this procedure should stimulate the systematic integration of professional knowledge into learners' semantic networks.

The second element of professional conceptual change model (more space for new personal experiences with learning theory-based beliefs) was incorporated by giving students the opportunity to carry out learning experiments and try out sustainable learning methods in each seminar session (column 5 in Table 1). For example, in session 6, the students carried out a school-based learning experiment known as mirror drawing addressing the topic of "memory systems and knowledge types." By attempting to reproduce star templates on the basis of their mirror images only, the students discovered that procedural memory contents require practice (repetition), whereas semantic memory contents (facts) also require a more extensive processing of the information. As this example illustrates, each session was organized as a "didactical double-decker" (with the addressed learning topic accompanied by 
associated teaching and learning activities). The relevant phenomena and concepts were thus not merely presented, but also made tangible and experienced [80].

Table 1. Overview of the university course: block and session number, element of professional knowledge, session content, learning experiences, whether a homework assignment (conceptual change text or reflection task on one's own learning) was given.

\begin{tabular}{|c|c|c|c|c|c|}
\hline Block & Session & $\begin{array}{l}\text { Professional } \\
\text { Knowledge }\end{array}$ & Content & Learning Experience & $\begin{array}{c}\text { Homework } \\
\text { Assignment }\end{array}$ \\
\hline $\mathrm{O}$ & 1 & \multicolumn{4}{|c|}{ Organizational session } \\
\hline \multirow{4}{*}{ I } & 2 & PPK & $\begin{array}{l}\text { Multi-store model of } \\
\text { memory }\end{array}$ & $\begin{array}{l}\text { Studies on attention, } \\
\text { chunking, elaboration }\end{array}$ & $x$ \\
\hline & 3 & CK & $\begin{array}{l}\text { Structure and function of } \\
\text { the brain }\end{array}$ & Concept mapping & $x$ \\
\hline & 4 & PCK & $\begin{array}{l}\text { Students misconceptions } \\
\text { (brain) }\end{array}$ & $\begin{array}{l}\text { Classifying pupils' } \\
\text { misconceptions }\end{array}$ & $x$ \\
\hline & 5 & Linking session & \multicolumn{3}{|c|}{ Designing teaching materials } \\
\hline \multirow{4}{*}{ II } & 6 & PPK & Learning strategies & $\begin{array}{l}\text { Inventory of students' } \\
\text { own learning strategies }\end{array}$ & $x$ \\
\hline & 7 & CK & $\begin{array}{l}\text { Memory systems \& } \\
\text { knowledge types }\end{array}$ & $\begin{array}{c}\text { School-based learning } \\
\text { experiments }\end{array}$ & $\times$ \\
\hline & 8 & PCK & Self-regulated learning & Storylining & $\times$ \\
\hline & 9 & Linking session & \multicolumn{3}{|c|}{ Designing teaching materials } \\
\hline \multirow{4}{*}{ III } & 10 & PPK & $\begin{array}{l}\text { Process model of } \\
\text { memory }\end{array}$ & Placemat & $\times$ \\
\hline & 11 & CK & $\begin{array}{c}\text { Cellular mechanisms of } \\
\text { learning }\end{array}$ & $\begin{array}{l}\text { Structure formation } \\
\text { technique }\end{array}$ & $\times$ \\
\hline & 12 & PCK & $\begin{array}{l}\text { Learning aids \& } \\
\text { instructional support }\end{array}$ & Network method & $\times$ \\
\hline & 13 & Linking session & \multicolumn{3}{|c|}{ Designing teaching materials } \\
\hline $\mathrm{O}$ & 14 & \multicolumn{4}{|c|}{ Organizational session } \\
\hline
\end{tabular}

The third conceptual element (refuting false single beliefs) was applied in the intervention group by utilizing conceptual change texts. According to Woolfolk-Hoy et al. [60], the formatting of these texts provides an opportunity to explicitly analyze and reflect on one's personal misconceptions. The comparison group instead received reflection tasks on their own learning in the course. Concretely, the students were asked to review the session contents and learning experiences once again and reflect on their learning gains during the course. Information was given in the course sessions that could potentially help students critically engage with neuromyths. In Session 3 (structure and function of the brain), for example, the students learned that the brain consists of two hemispheres that are able to exchange information with each other via a connecting structure. In Session 11 (cellular mechanisms of learning), they learned that the brain always works holistically and within a network. This knowledge should have been sufficient for the students to reject the neuromyth that coordination exercises improve the exchange between the left and right brain hemispheres. The goal of the reflection tasks on the students' own learning in the course was to stimulate implicit reflection. Consequently, the intervention and comparison groups differed in their type of reflection on neuroscientific facts. Neuromyths were explicitly addressed in the intervention group, while the comparison group needed to make contrasts and draw conclusions themselves. The students worked on both types of reflection tasks individually at home (column 6 of Table 1). These were distributed during nine content-related sessions and needed to be submitted one week later. In case of absence, the students returned the texts two weeks later. Submitting the homework was mandatory, but occurred anonymously using a code system and remained ungraded. Students were instructed to complete the position statements before and after 
reading the conceptual change texts or reflection tasks on their own learning honestly and intuitively and not to conduct any research.

\subsection{Conceptual Change Texts}

Seven conceptual change texts refuting neuromyths that are widespread among pre-service biology teachers [24] were constructed: Only use 10\% of our brains, Information is stored in specific locations (hard drive), Effectiveness of Brain Gym, Existence of learning styles, Learn best before age 3, Learning while you sleep, and Blocked learning is better than interleaved. For reasons of course organization (maximum homework load), we were not able to employ conceptual change texts for all 11 neuromyths on our questionnaire. However, the neuromyths Learning differences due to the use of different hemispheres and Logic in the left hemisphere/creativity in the right were thematically similar to Effectiveness of Brain Gym. Critical periods of childhood development and Genetically-determined number of cells determines learning thematically overlapped with Learn best before age 3 . Thus, these four neuromyths were integrated into the conceptual change texts for Effectiveness of Brain Gym and Learn best before age 3 in the form of a short paragraph. Two conceptual change texts concerning scientifically correct concepts were mixed in with the conceptual change texts on neuromyths so that students would not learn to expect every text to deal with a neuromyth. These referred to the little-believed scientific concepts Boys have bigger brains than girls and When a brain region is damaged other parts of the brain can take up its function. The texts were constructed as follows: The first page had a free text field in which the students were to take a position with regard to a statement (neuromyth). This was followed by 2-2.5 pages of text, a reference list, and recommendations for further scientific literature. The last page consisted of another free text field in which students were instructed to reflect again on the position they had taken at the beginning and supplement or revise it as needed. The text itself had the function to first introduce the relevant misconception and then ask whether they could really be true. Egbers and Marohn [74] explain that questions incorporated into the text or immediately following it can particularly facilitate the development of a scientific concept because they require the learner to actively, deliberately engage with and compare his or her original conceptions with the new information in the text. Afterwards, a scientific clarification was provided in which arguments against the misconception were presented one by one; it was thus designed as a strong refutation. According to Egbers and Marohn [74] and Beerenwinkel et al. [73], the texts fulfill Posner's et al. [54] conceptual change conditions: dissatisfaction with the previous misconception, intelligibility, plausibility and fruitfulness of the new scientific concept. The conceptual change texts used in this study made learners dissatisfied by addressing them directly and pointing out contradictions through the repeated use of language highlighting contrasts between the misconception and the corresponding scientific concept. An attempt was made to make the scientific concept intelligible through the use of everyday/descriptive language and a moderate number of technical terms and by avoiding complicated sentences with many subordinate clauses. Attention was drawn to the main arguments through the use of underlining and bold type. According to Beerenwinkel et al. [73], headings are used within the conceptual change text to focus the disparity or overlap between students' own ideas and the scientific view. The most important elements in the text were explicitly labeled as such and the information density was restricted to a moderate level. The texts' plausibility was increased through the use of a reference list and explicitly citing the scientific literature. Furthermore, we attempted to give each text a clear argumentation structure with memorable headings in order to make them convincing for the reader (e.g., learning styles tests are an unreliable measure!). Impulses for further/critical thought during subsequent teaching and learning and practical, everyday examples were included to demonstrate the fruitfulness of the scientific concept.

The two texts on scientifically-correct concepts were structured in the opposite manner: They first described the little-believed scientific concept, then demonstrated inappropriate implications for teaching and learning that can be derived from this scientific concept, before finally highlighting the "kernel of truth" that nevertheless remains. 


\subsection{Evaluation Methods}

Data collection took place during the organizational sessions of the course via paper-and-pencil tests (pre-post-design) and took approximately one hour. Participation in the evaluation was voluntary and the students provided their informed written consent to use the data for research purposes. They were informed that the goal of the study was to collect information on their current state of knowledge and attitudes towards the topic of learning and the brain, and that the anonymity of their data would be ensured via a coding system. They were further notified that they could withdraw from participation at any time without consequences. The authors strictly handled student anonymity and ethical issues.

In addition to questions asking for sociodemographic data (age, gender, field of study, year of study/training), average grade on their secondary school completion exams (Abiturnote), and most recent grade in science (biology), the participants completed eight test instruments. Five of those instruments were analyzed in answering the research questions posed in this paper. Professional knowledge was measured via three self-constructed knowledge tests. CK about curricular content in neuroscience was measured via 11 multiple-choice items with four distractors each. The tested content referred to the structure and function of the brain, memory systems $\mathcal{E}$ knowledge types and cellular mechanisms of learning in roughly equal measure and thus covered all three CK topics addressed in the seminar (Table 1). PPK about the psychology of human learning was measured via 19 open-ended and closed-ended items: Eight open-ended and six closed-ended items addressed cognitive psychology topics covered during the seminar (multi-store model of memory, learning strategies and process model of memory). Five closed-ended items (multiple-choice) additionally addressed general pedagogical psychology topics related to learning and the brain that might have been familiar to students from other university courses. These items were taken or adapted from instruments on educational science knowledge developed as part of the KeiLa [81] and SPEE studies [82]. PCK about instructional strategies for sustainable learning (including how to deal with students' conceptions of the structure and function of the brain) was measured via 18 items. With the exception of two closed-ended, multiple-choice items, all items were open-ended and only asked about content covered during the seminar (in equal measure: students' misconceptions about the brain, self-regulated learning and learning aids $\mathcal{E}$ instructional support). Translated example items from all three knowledge tests can be found in Table 2 below.

Table 2. Overview of knowledge tests and example items.

\begin{tabular}{cc}
\hline Instrument & Example Item (Translated from German) \\
CK about curricular content in neuroscience & $\begin{array}{c}\text { Select the correct option (1 answer) } \\
\text { Which part of the brain is responsible for motor skills? } \\
\text { The cerebellum } \\
\text { The cerebrum } \\
\text { The corpus callosum } \\
\text { The forebrain }\end{array}$ \\
PPK about psychology of human learning & $\begin{array}{c}\text { Which of the following are components of working memory? } \\
\text { Central executive } \\
\text { Semantic memory } \\
\text { Iconic storage }\end{array}$ \\
PCK about instructional strategies for & Phonological loop \\
sustainable learning & Name three school experiments on the topic of learning. \\
\hline
\end{tabular}


Questionnaires on learning theory-based beliefs [83] and false single beliefs [77] were deployed to evaluate Elements 2 and 3 of the seminar (RQ2 + RQ3). Post-test reliabilities are reported in Table 3. The instrument for learning theory-based beliefs asked about beliefs concerning teaching and learning in biology and consisted of two scales with seven items each (transmissive and constructivist beliefs). The instrument for false single beliefs asked about misconceptions about learning and the brain. It consisted of 11 items asking whether respondents agreed with the neuromyths discussed in the theoretical section above. These items were mixed in with 11 further items concerning scientific concepts on learning and the brain that are not addressed in this article. 4-point Likert scales (Strongly agree/Somewhat agree/Somewhat disagree/Strongly disagree) were utilized in all questionnaires.

Table 3. Overview of questionnaires: instrument, scales, number of items, and reliability.

\begin{tabular}{llc}
\hline Instrument & Scales (Number of Items) & $\alpha_{\text {Post }}$ \\
\hline Learning theory-based beliefs [83] & & \\
Beliefs about teaching \& learning in biology & $\bullet$ Transmissive beliefs (7) & 0.87 \\
& $\bullet$ Constructivist beliefs (7) & 0.88 \\
\hline False single beliefs [77] & & \\
Misconceptions about learning \& the brain & $\bullet$ Neuromyths (11) & 0.78 \\
\hline
\end{tabular}

The testing time for the comparison group had to be reduced to $30 \mathrm{~min}$ for reasons of course organization. Thus, only one instrument (neuromyths) can be comparatively evaluated. The comparison group was not evaluated with the instruments for professional knowledge and learning theory-based beliefs (Elements 1 and 2 of the university course). The group of students from Summer Semester 2016 thus only represents an appropriate comparison group with respect to Research Question 3 (conceptual change texts). Following the post-test, the students in the intervention group additionally received a one-page text explaining the three elements of the seminar. After reading this text, the students were asked in open-ended questions to honestly report the extent to which they had (a) perceived and (b) used these three elements. The open-ended format was selected in order to provide students with an opportunity to give nuanced answers and express any praise or critiques they had.

\subsection{Data Analysis}

Data analysis was conducted on the basis of classical test theory using the software SPSS 24. The levels of PPK, CK, PCK, learning theory-based beliefs and misconceptions were determined by calculating mean values. The level of professional knowledge was calculated as the percentage of the maximum number of possible test points achieved. $t$-tests were conducted to test for differences in scores for professional knowledge and learning theory-based beliefs before and after completing the course. Effect sizes $d$ were reported [84]. The degree of linkage between the knowledge areas was investigated indirectly by comparing the associations between PPK, CK, and PCK before and after the course. These were determined by means of correlational analyses (Pearson) and tested for differences using Fisher's $z$-transformations [85]. The effectiveness of the conceptual change texts on false single beliefs (neuromyths) was analyzed using a two-factor variance analysis (ANOVA) with (intervention vs. comparison) group as the group factor, the measurement point (pre- vs. post-test) as the repeated measures factor and endorsement with neuromyths as the dependent variable. Wilcoxon tests were conducted to determine whether the endorsement of individual neuromyths (on an ordinal scale) had been professionalized from pre to post as a result of the use of corresponding conceptual change texts. Effect sizes, $r$, were reported for these results [86]. For better comparability with the study on pre-service biology teachers cited in the theory section, we also calculated the percentage of respondents endorsing the neuromyths addressed in the conceptual change texts by recoding the 4-point scale into a binary format (agree/disagree). The students' open-ended answers on their perceptions and use of the seminar elements were coded on a three-level scale (negative, neutral, positive student statements) and described in terms of percentage. Associations with students' post-test performance on each element 
were evaluated by means of correlational analyses (Spearman). All results were significant at the 0.05 level unless otherwise stated. Pairwise comparisons were Bonferroni-corrected to the 0.05 level.

\section{Results}

\subsection{Professional Knowledge}

Table 4 reports the pre-/post-mean percentages, standard deviations, $t$-test results $(t$ and $p)$ and effect sizes $d$ for the intervention group.

Table 4. Pre-/ post-comparison of professional knowledge for the intervention group $(n=40)$.

\begin{tabular}{cccccc}
\hline Professional Knowledge & Pre-Mean in \% (SD) & Post-Mean in \% (SD) & $\boldsymbol{t}$ & $\boldsymbol{p}$ & $\boldsymbol{d}$ \\
\hline PPK & $31.38(8.00)$ & $55.99(17.41)$ & -12.87 & $\leq 0.001$ & 1.3 \\
CK & $32.27(14.55)$ & $51.59(15.86)$ & -5.81 & $\leq 0.001$ & 1.3 \\
PCK & $24.17(8.47)$ & $50.97(15.72)$ & -15.47 & $\leq 0.001$ & 1.7 \\
\hline
\end{tabular}

There was a highly significant increase in students' scores in all three areas of professional knowledge, with a large [87] effect size. The students achieved an average of around one-third of the maximum number of points on the pre-test, but more than half the possible number of points on the post-test. The standard deviations became larger from pre- to post-test, particularly for PPK and PCK. The correlational analyses at pre-test only revealed a relation between PPK and PCK with respect to the topic of learning and the brain $(r=0.451 ; p=0.003)$. This correlation was not very pronounced [88]. There was no relation between CK and PCK $(r=-0.007, p=0.964)$ or CK and PPK $(r=0.183, p=0.260)$ at pre-test. However, there were correlations between all three areas of professional knowledge at post-test. The correlation between CK and PCK was at a moderate level $(r=0.560, p \leq 0.001)$, and the relation between CK and PPK was at a low level $(r=0.488, p=0.001)$. The correlation between PPK and $\operatorname{PCK}(r=0.660, p \leq 0.001)$ was also significantly higher at post-test than at pre-test $\left(z_{P P K / P C K}=-3.17\right)$ and reached a moderate level.

We were able to code 35 student statements about their perceptions of Element 1 of the university course (linking professional knowledge). Of these, $65.7 \%$ were positive, $25.7 \%$ were neutral, and $8.6 \%$ were negative. No correlations were found between students' perceptions about linking professional knowledge and their professional knowledge at post-test for either PPK $(r=-0.208, p=0.230, n=35)$, CK $(r=-0.160, p=0.357, n=35)$, or PCK $(r=-0.102, p=0.562, n=35)$.

\subsection{Learning Theory-Based Beliefs}

Table 5 reports the pre-/post-means, standard deviations, $t$-test results $(t$ and $p)$ and effect sizes $d$ for the intervention group.

Table 5. Pre-/post-comparison for beliefs about teaching and learning (intervention group, $n=40$ ).

\begin{tabular}{cccccc}
\hline $\begin{array}{c}\text { Beliefs about Teaching \& } \\
\text { Learning in Biology }\end{array}$ & Pre-Mean (SD) & Post-Mean (SD) & $\boldsymbol{t}$ & $\boldsymbol{p}$ & $\boldsymbol{d}$ \\
\hline Constructivist beliefs & $3.59(0.43)$ & $3.58(0.41)$ & 0.30 & 0.765 & 0.0 \\
Transmissive beliefs & $2.29(0.65)$ & $2.03(0.64)$ & 3.95 & $\leq 0.001$ & 0.4 \\
\hline
\end{tabular}

Endorsement of constructivist beliefs about teaching and learning was already very strong at pre-test (3.59 on a 4-point Likert scale) and did not increase from pre- to post-test. Endorsement of transmissive beliefs about teaching and learning was less widespread at pre-test and further declined in the post-test with a small [87] effect size. The pre- and post-standard deviations exhibited similar values. 
We were able to code 38 student statements about their perceptions of Element 2 of the university course (personal learning experiences). Of these, $81.6 \%$ were positive, $13.2 \%$ were neutral and $5.3 \%$ were negative. No associations were found between students' perceptions about personal learning experiences and their endorsement of learning theory-based beliefs. This was true with respect to both constructivist $(r=0.017, p=0.918, n=38)$ and transmissive $(r=-0.012, p=0.941, n=38)$ beliefs about teaching and learning.

\subsection{Misconceptions (Neuromyths)}

The two-factor analysis of variance with repeated measurements revealed significant main effects for group (intervention vs. control: $F(1,55)=39.51, p \leq 0.001, \eta_{p}^{2}=0.418$ ) and measurement point (pre- vs. post-test: $F(1,55)=89.21, p \leq 0.001, \eta_{p}{ }^{2}=0.619$ ). There was a statistically significant interaction between measurement point and group: $F(1,55)=60.67, p \leq 0.001, \eta_{p}^{2}=0.524$. In addition, Figure 1 depicts the mean endorsement levels for the two groups at pre- and post-test. The students who worked through seven conceptual change texts endorsed 11 neuromyths at post-test to a lesser extent than students in the comparison group, who completed tasks asking them to reflect on their own learning.

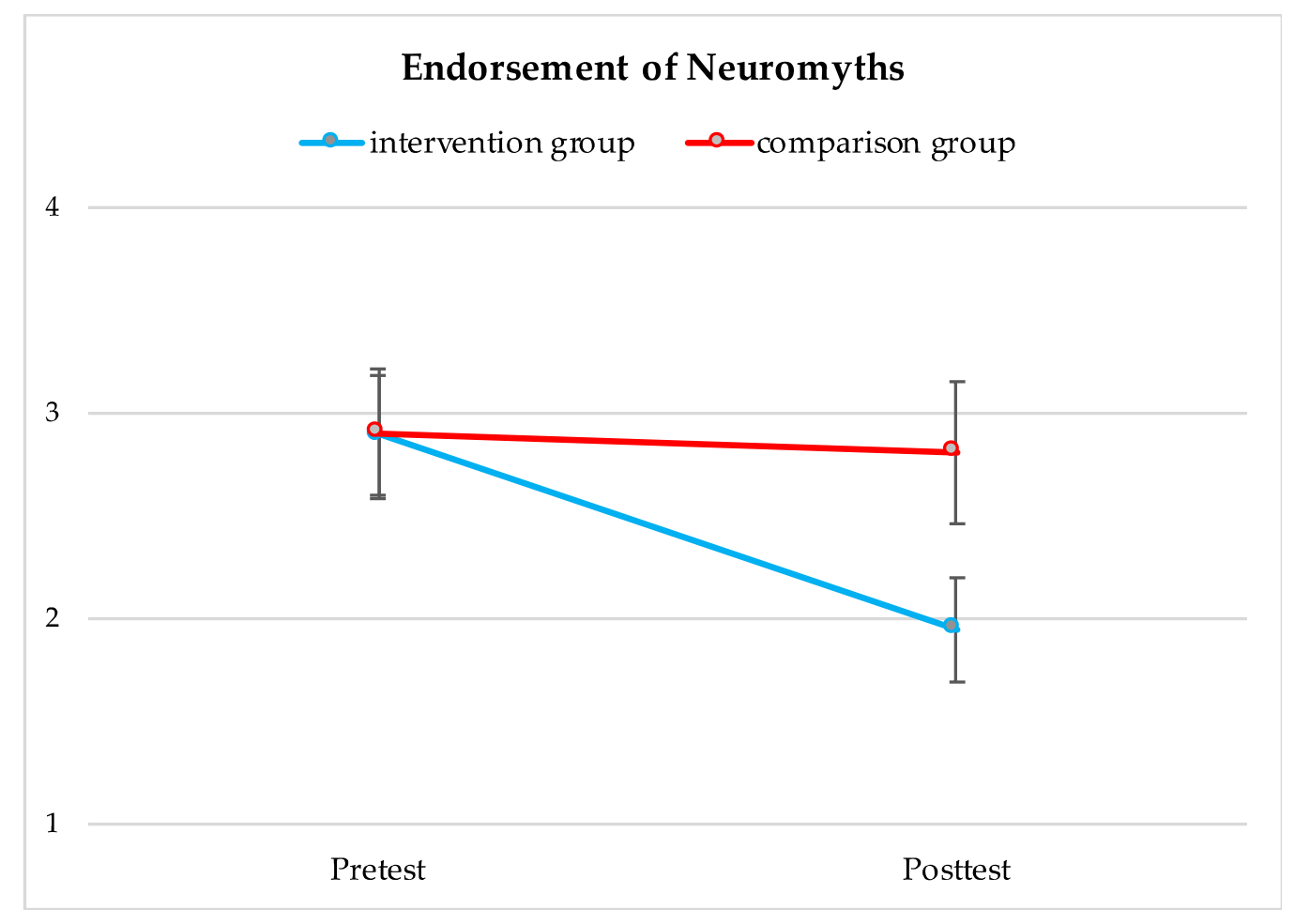

Figure 1. Endorsement of 11 neuromyths in the intervention group (blue) and comparison group (red) at pre- and post-test ( $4=$ strongly agree, $3=$ Somewhat agree, $2=$ Somewhat disagree, $1=$ Strongly disagree).

The university course only explicitly covered seven of the 11 neuromyths addressed in the questionnaire. Four neuromyths were only addressed through integration into other conceptual change texts. Thus, we also present the effects of the individual conceptual change texts used as part of the university course on the corresponding neuromyths. The results of the Wilcoxon tests for individual myths among the intervention group are listed in Table $6(z, p)$. The ranks, as an element of the Wilcoxon tests, are also presented in order to provide an overview of how many students' endorsement of a given misconception declined $(-)$, stayed the same $(0)$, or rose $(+)$ from pre- to post-test (after reading all of the conceptual change texts). The results are depicted according to their effect size $r$. The table further reports the percent endorsing each misconception at pre- and post-test (recoding the 4-point scale into a binary format: agree/disagree). 
Table 6. Percentages of the intervention group endorsing the neuromyths addressed in the conceptual change texts at pre- and post-test, results of the Wilcoxon tests, and effect sizes $r$.

\begin{tabular}{cccccccccc}
\hline Misconception (Neuromyth) & \multicolumn{2}{c}{ Endorsement (\%) } & \multicolumn{3}{c}{ Ranks } & & & $\boldsymbol{z}$ & $\boldsymbol{r}$ \\
\cline { 2 - 7 } & Pre- & Post- & - & $\mathbf{0}$ & + & & & & \\
\hline $\begin{array}{c}\text { Information is stored in specific } \\
\text { locations (hard drive) }\end{array}$ & 83 & 5 & 35 & 5 & 0 & -5.28 & $\leq 0.001$ & 0.590 \\
\hline $\begin{array}{c}\text { Learning while you sleep } \\
\text { Existence of learning styles }\end{array}$ & 68 & 3 & 33 & 5 & 1 & -5.05 & $\leq 0.001$ & 0.565 \\
\hline $\begin{array}{c}\text { Blocked learning is better } \\
\text { than interleaved }\end{array}$ & 58 & 3 & 29 & 11 & 0 & -4.82 & $\leq 0.001$ & 0.538 \\
\hline Only use 10\% of the brain & 48 & 10 & 28 & 9 & 3 & -4.05 & $\leq 0.001$ & 0.453 \\
\hline Learn best before age 3 & 78 & 38 & 26 & 12 & 2 & -3.93 & $\leq 0.001$ & 0.439 \\
\hline Effectiveness of Brain Gym & 90 & 55 & 21 & 12 & 7 & -3.28 & 0.001 & 0.367 \\
\hline
\end{tabular}

Following Cohen's [89] interpretation, the conceptual change texts had strong effects on four misconceptions $(0.538 \leq r \leq 0.590)$. The strongest effects were obtained for Information is stored in specific locations (hard drive), Learning while you sleep and Existence of learning styles. The university course and its conceptual change texts had only a moderate effect on the neuromyths Only use $10 \%$ of the brain, Learn best before age 3 and Effectiveness of Brain Gym. The pre-/post-comparison reveals that the large effect sizes did not arise from strong endorsement at pre-test and thus a high potential for conceptual change. Of the misconceptions that were strongly endorsed at pre-test, some declined markedly (e.g., Information is stored in specific locations), and others declined more moderately (e.g., Effectiveness of Brain Gym). The ranks show that the majority of the students endorsed the neuromyths less (-) or to the same extent (o) after completing the course. However, there were some students whose endorsement of the neuromyths increased (+), e.g., for Effectiveness of Brain Gym.

We were able to code 38 student statements about their perceptions of Element 3 of the university course (conceptual change texts). We found that $73.7 \%$ of the students described their perceptions of the conceptual change texts as positive, $21.1 \%$ as neutral, and $5.3 \%$ as negative. No correlation was found between perceptions of the conceptual change texts and endorsement of neuromyths $(r=-0.055$, $p=0.745, n=38)$. There was a moderate negative correlation $(r=-0.548, p=0.028, n=16)$ between use of the texts and endorsement of neuromyths at post-test.

\section{Discussion}

The evaluation of the university course, according to the professional conceptual change model, revealed positive results with respect to all three research questions. Professional knowledge increased in all three areas (PPK, CK, and PCK). The strong effect for PCK can be evaluated particularly positively, because a relationship between PCK and students' performance has been demonstrated [90]. The stronger effect, in comparison to PPK and CK, can likely be explained by the fact that in the seminar PPK and CK content were also taught with reference to the students' later roles as biology teachers, and the linking sessions on constructing teaching materials focused on PCK. Thus, even though the seminar was divided into three parts, the share devoted to PCK was predominant. According to the amalgam hypothesis, PCK is a "special amalgam of content and pedagogy" [16] (p. 8). Although empirical analyses do not confirm this [91-93], the development of PCK in the seminar may nevertheless have been influenced by CK about curricular content in neuroscience and PPK about the psychology of human learning. Consequently, the stronger increase in PCK about instructional strategies for sustainable learning may have been the result of a synergy effect. Indications for this can be found in the fact that an association between PCK and CK about curricular content in neuroscience was found at post-test but not at pre-test, and that the association between PPK and PCK significantly increased. Other 
studies on biological topics $[91,94,95]$ have found moderate correlations between CK and PCK. Thus, the pre-intervention associations for topics such as evolution are different than for learning and the brain. The association between PCK and PPK is stronger for the topic of learning and the brain than for evolution, for example [91]. This reaffirms Meier et al.'s [78] recommendation of measuring and investigating professional knowledge in a subject-specific and topic-specific way. The lack of correlation found between CK and PPK at pre-test is in line with previous studies [91,94,95]. It proves that calls for more neuroscience in teacher education, like those issued by Howard-Jones [46] and Papadatou-Pastou et al. [45], alone does not seem to be sufficient. The lack of correlations between CK/PCK and CK/PPK at pre-test can be seen as an indication that, in accordance with diSessa's knowledge-in-pieces theory [49], students are in fact not able to effectively combine their neuroscientific knowledge with elements of PCK and PPK. The interleaved teaching of PPK, CK, and PCK on the topic of learning and the brain increased the correlations between the areas of knowledge with respect to learning and the brain. On the basis of this, we conclude that the linking professional knowledge element of the university course seems well-suited for simultaneously increasing professional knowledge in all three knowledge areas. The extent to which the formation of coherent professional knowledge, as called for by Schnotz [58], goes along with this, cannot be tested with the present data and methods. Wider differences in student performance on PPK and PCK emerged after students completed the university course. Students had positive perceptions of the linking professional knowledge element of the university course, but there was no relation between these perceptions and post-test performance on professional knowledge. Given these results, we would explain the difference in performance by pointing to differences in the learning strategies applied by the students [96] and differences in their engagement in using the university course [97]. The latter might have varied because the seminar was not a graded course for some students. Students' performance on the CK test likely did not vary as widely because multiple-choice items were used instead of open-ended items.

The analysis of learning theory-based beliefs revealed a decline in transmissive beliefs about teaching and learning. The reduction in the belief that teachers can transfer knowledge and information to their students can be seen as a desirable, positive development in terms of teachers' professional competence [98]. While we were not able to determine in this study whether this change has an influence on the students' professional behavior, the current state of research allows us to speculate that constructivist learning concepts exert a more positive influence on teachers' behavior and students' learning performance than transmissive ones [63]. The small effect size is in conformity with expectations, as beliefs are considered far more difficult to change than knowledge [61]. In addition, this might be because the formation of appropriate beliefs is not explicitly taught and supported in the university course. In fact, our results represent a secondary effect, and it seems plausible that this effect could be increased by explicitly addressing learning theory-based beliefs in the seminar as well. However, the personal experiences element of the university course, which was supposed to implicitly professionalize students' beliefs about teaching and learning, was viewed most positively of all three elements. There was no association between perceptions of the personal experiences element of the university course and post-test performance on learning theory-based beliefs. In accordance with Helmke [97], we would also explain the effects on transmissive beliefs about teaching and learning by pointing to differences in the use of this element of the university course.

Our finding that transmissive beliefs decline but constructivist beliefs remain unchanged is similar to Brauer et al.'s results [62]. Therefore, Brauer at el. also argue in favor of considering both dimensions (constructivist and transmissive) in university instruction. The concept of sustainable learning addressed in the university course was based on a constructivist approach. The reason for the lack of changes might be that neither transmissive nor constructivist beliefs about teaching and learning were explicitly addressed in the intervention. However, the explanation might also lie in methodological aspects. Given the intervention group's sample size $(n=40)$, we cannot exclude the possibility of small effects. Many intervention studies involving university seminars face this problem [99]. However, the quite high scores for constructivist beliefs about teaching and learning at 
pre-test (3.59 out of 4 points) lead us to suspect a ceiling effect instead. According to Buelens et al. [100], transmissive beliefs generally decline during university education, and constructivist beliefs become stronger. The students in our sample were in their seventh semester of studies on average and confirmed this trend.

The percentage of students who endorsed neuromyths in the pre-test largely matched Grospietsch and Mayer's [24] results for pre-service biology teachers ( $N=401$ university students and post-graduate trainees). Only for the myth Only use 10\% of our brains was the intervention group's endorsement lower, by 10 percentage points. However, their endorsement of the myth Learning while you sleep was 16 percentage points higher. The $10 \%$ myth was endorsed by roughly half of the pre-service teachers before they began the university course, similarly to findings by Dündar and Gündüz [41] and Papadatou-Pastou et al. [45]. The pre-test results for Existence of learning styles, with 95\% endorsement, were also analogous to findings by Dündar and Gündüz [41], Kim and Sankey [44] and Papadatou-Pastou et al. [45]. Effectiveness of Brain-Gym was endorsed by $90 \%$ of our sample, more frequently than in Dündar and Gündüz [41], Kim and Sankey [44] and Papadatou-Pastou et al.'s [45] studies. However, this might have been due to the lack of an I don't know answer option. Thus, our results are largely in line with the results of other studies of pre-service teachers' endorsement of neuromyths.

The results on endorsement of neuromyths among the intervention and comparison groups demonstrate the superiority of conceptual change texts (explicit reflection) over reflection tasks on one's own learning (implicit reflection). Cakir et al. [68] also found that an experimental group taught using conceptual change text-oriented instruction performed better than a control group taught using traditional instruction. The linking professional knowledge and personal learning experiences elements of the university course plus implicit reflection (reflection tasks on one's own learning) do not seem to be sufficient to professionalize students' misconceptions about the topic of learning and the brain. Because we did not measure professional knowledge and learning theory-based beliefs in the comparison group, we cannot exclude the possibility that they were present to a different extent or increased in the intervention group, and that this had an influence on the changes in misconceptions. Moreover, although our study was designed to keep all content and learning experiences in the course sessions constant, we cannot exclude the possibility that the groups of students in different semesters learned differently. Similarly, data on motivational and affective factors related to working through the two types of reflection tasks were not collected in this study and might have contributed to the differences in results. For example, conceptual change texts might be more motivating for university students. In light of these aforementioned limitations, we would like to mention just two arguments in favor of the superiority of conceptual change texts: On the one hand, our results support Weisberg et al.'s [101] finding that participation in mandatory cognitive neuroscience classes alone is insufficient to critically engage with neuroscientific information. Explicitly reflecting about neuromyths appears to be more effective. On the other hand, our results empirically confirm the effectiveness of Papadatou-Pastou et al.'s [45] call (based on psychological work on misconceptions [102-104]) to directly refute neuromyths. The methodological element of conceptual change texts proved to be an effective, evidence-based way of translating neuroscience content into a language shared by teachers [45]. Moreover, it provides support to Chi's [51] recommended instructional strategy of refuting misconceptions, derived from conceptual change theory. Given that there was a large time lag between working through some of the contextual change texts and the post-test (up to 12 weeks), that the conceptual change texts were worked through only once and not explicitly reviewed in the seminar, that some neuromyths were only addressed in the context of others, and that misconceptions are generally considered to be difficult to change, we consider the intervention effects on the endorsement of neuromyths to be quite positive.

Endorsement declined from pre- to post-test for all seven misconceptions addressed in the conceptual change texts employed with the intervention group. The effect of three conceptual change texts was lower than the effects of the other four texts. For the $10 \%$ myth, the lower effect size 
might have been because this myth was endorsed least often in the pre-test (48\%) and had the longest time lag to post-test (= it was the first conceptual change text the students worked through). This neuromyth might have had less potential for conceptual change and/or was not remembered sufficiently. The sequence of conceptual change texts, including the mixed-in conceptual change texts on scientific concepts, was predetermined by the study design. More systematic coordination of the seminar sessions and conceptual change texts (both chronologically and thematically) might have increased the effects. We also explain the two other neuromyths with lower effect sizes with reference to content: The argumentation structure of the neuromyth Effectiveness of Brain Gym, for example, is very complex and has been frequently described in prior research on neuromyths as overlapping with the myths Learning differences due to the use of different hemispheres and Logic in the left hemisphere/creativity in the right [105]. For reasons of course organization, the two other aforementioned neuromyths were integrated into the conceptual change text on Effectiveness of Brain Gym. Lower effect sizes were found here as well as for the conceptual change text on Learn best before age 3 (which integrated the neuromyths Critical periods of childhood development and Genetically-determined number of cells determines learning) than for the conceptual change texts that only addressed one neuromyth. It is possible that these conceptual change texts did not completely convince the students because they were too complex or mixed up lines of argumentation related to several neuromyths. On the basis of our results, addressing only one misconception per conceptual change text in a differentiated way seems to be the more effective strategy. For this purpose, it seems necessary to investigate and describe neuromyths and their series of fallacies and exaggerations that lead to inaccurate implications for teaching and learning in a detailed way. The research discourse on neuromyths argues strongly in favor of interdisciplinary collaboration [106-110]. On the basis of this study, we also recommend such collaboration on the construction of conceptual change texts. Experts in subject didactics must describe and explain individual neuromyths' lines of argumentation in the language of education [111]. However, neuroscientists and cognitive psychologists must supply the scientific arguments against these neuromyths.

The fact that endorsement of the addressed neuromyths was not eliminated completely in our results can be explained with reference to the negative association we found with the use of the conceptual change texts, in accordance with Helmke's [97] offer-and-use-model. Students who indicated that they had not read the texts at all or did not read them thoroughly enough (= negative statements concerning use) did not reduce their endorsement of neuromyths. This study did not investigate how the students evaluated the construction of various conceptual change texts. The lines of argumentation in the conceptual change texts were derived from theories on neuromyths. Texts whose design is evaluated more positively, e.g., because they better address fallacies in learners' individual lines of argumentation, might have been more effective than others. Moreover, studies by Pettito and Dunbar [112] demonstrate that university students can stubbornly hold onto their original concepts despite receiving empirical demonstrations and theoretical explanations. Newton and Miah [113] demonstrated this specifically for the neuromyth regarding the existence of learning styles. These findings support our study's and Kim and Sankey's [44] theoretical assumptions that neuromyths are beliefs that are not easy to change. In addition, Newton and Miah [113] warn of a "backfire effect", a phenomenon in which attempts to address myths and misunderstandings can lead to even stronger endorsement of these myths. Although they might be chance events, the results of this study support this, as some neuromyths were endorsed more frequently after the seminar than before. We cannot conclusively determine whether backfire effects were present, how they arose, and how they might have been effectively avoided. Nevertheless, our results can be seen as a first indication that more attention should be paid to the phenomenon of backfire effects in future studies. All in all, the results of this study indicate that interventions concerning endorsement of neuromyths must begin deep in participants' belief systems.

Beerenwinkel, Parchmann and Gräsel's [73] results concerning chemistry content demonstrate that conceptual change texts are more effective than scientific texts among school students. Conceptual 
change texts also respond to Papadatou-Pastou et al.'s [45] call to debunk well-known neuromyths and train students to critically consume constantly developing and changing neuroscientific findings. Similarly to Uzuntikyaki and Geban [114], the study presented here investigated a combination of text-based instruction and further methodological elements of the university course. According to Beerenwinkel and Parchmann [115], conceptual change texts must be integrated into cognitively-stimulating learning environments in order to obtain stronger learning effects. However, we cannot conclude on this basis how conceptual change texts about neuromyths might function independently of the university course on the topic of learning and the brain developed here. We can only emphasize that a university course in accordance with the professional conceptual change model has an effect on pre-service teachers' misconceptions when individual reflection about one's misconceptions is explicitly integrated into teacher education. However, the students perceived the conceptual change texts element of the university course very positively. The facts that the intervention group consisted of two courses in two different semesters and investigations were conducted within the framework of a field study (e.g., without randomization) certainly limit the conclusions that can be drawn on the basis of the present study. Nevertheless, despite all of the aforementioned methodological limitations, our research findings can be interpreted as indicating that a teaching and learning setting in accordance with the professional conceptual change model has positive effects on learning, which we attribute to the key conceptual elements - namely more deeply linking professional knowledge, personal experiences with learning theory-based beliefs, and explicit reflection on individual misconceptions.

\section{Conclusions}

This study demonstrated that the teaching and learning model of conceptual change and its implications for teaching and learning can be transferred to university teacher education. Whether it is equally promising for scientific research on professions and effective for academic teaching and learning on topics other than learning and the brain must still be evaluated. To this end, further experimental and quasi-experimental studies are necessary to systematically test for learning gains (knowledge, beliefs) and their motivational and emotional determinants. Furthermore, we were able to demonstrate that conceptual change theory is well-suited to designing ways to link the professional knowledge areas (PPK, CK, and PCK) in an elaborate, cognitively-stimulating manner. In our opinion, more systematic data on preconceptions should be collected in the university context. Existing findings on preconceptions should be integrated into professional models $[15,16]$ as well as Chi's categorization approach [51], whose instructional recommendations were found to be effective in our study. Attempts to collect data on preconceptions and to develop interventions must consider what quality of preconceptions (single beliefs, mental models, categories, schemas) they are seeking to address. Different measurement instruments and conceptual change instructions are necessary depending on the quality of the preconceptions that are to be changed.

The results of the present study provide evidence that a university course in accordance with the professional conceptual change model has positive effects on professional knowledge on the topic of learning and the brain, learning theory-based beliefs, and misconceptions (neuromyths) among pre-service biology teachers. The results of this study also indicate that explicitly refuting misconceptions (e.g., via conceptual change texts) seems to be a suitable method for professionalizing pre-service teachers' misconceptions about the topic of learning and the brain. In light of findings by e.g., Papadatou-Pastou et al. [45], who provide evidence of neuromyths among pre-service teachers in other subjects, it seems necessary to initiate and systematically support conceptual change concerning neuromyths among more than just biology teachers. In the authors' view, both the university course and conceptual change texts employed in this study are suitable for the transfer to other subjects within university teacher education (professional development for university instructors may be necessary here) and professional development programs for in-service teachers. Moreover, the texts could help both university instructors and schoolteachers quickly obtain information about 
potential misconceptions among their learners and how to clear them up scientifically. Future studies should experimentally test whether conceptual change texts are superior to standard scientific texts on neuromyths.

Author Contributions: The project administration and funding acquisition were the responsibility of J.M. All authors developed the study concept and the methodology. F.G. developed the study materials, conducted the data collection and analyzed the data. This article is part of the PhD thesis of F.G. supervised by J.M. F.G. drafted the manuscript, and J.M. provided critical revisions. All authors approved the final version of the manuscript for submission.

Funding: This research was funded by the German Federal Ministry of Education and Research under the funding code 01JA1505. This project is part of the "Qualitätsoffensive Lehrerbildung", a joint initiative of the German Federal Government and the Federal States aiming to improve the quality of teacher training. The study was also supported by the Federal State of Hesse's LOEWE Special Focus Area "Desirable Difficulties in Learning," of which the authors are associate (F.G.) and full members (J.M.). The funding sponsors had no role in the design of the study; in the collection, analysis, or interpretation of the data, in the writing of the manuscript, or in the decision to publish the results. The authors are responsible for the content of this publication.

Acknowledgments: The authors would like to thank everyone who contributed to having the pre-service science teachers fill out the survey, as well as the students themselves.

Conflicts of Interest: The authors declare no conflict of interest.

\section{References}

1. Vosniadou, S. International Handbook of Research on Conceptual Change, 2nd ed.; Routledge: New York, NY, USA, 2013; ISBN 978-0-415-89882-9.

2. Nakhleh, M.B. Why Some Students Don't Learn Chemistry: Chemical Misconceptions. J. Chem. Educ. 1992, 69, 191. [CrossRef]

3. Alexander, P.A.; Winters, F.I.; Loughlin, S.M.; Grossnickle, E.M. Students' Conceptions of Knowledge, Information, and Truth. Learn. Instr. 2012, 22, 1-15. [CrossRef]

4. Inagaki, K.; Hatano, G. Young Children's Naive Thinking about the Biological World. In Developmental Psychology; Psychology Press: New York, NY, USA, 2002; pp. 2002-2222. ISBN 978-1-84169-041-4.

5. Kattmann, U.; Duit, R.; Gropengießer, H.; Komorek, M. Das Modell Der Didaktischen Rekonstruktion-Ein Rahmen Für Naturwissenschaftsdidaktische Forschung Und Entwicklung. ZfDN 1997, 3, 3-18.

6. Duit, R.; Gropengießer, H.; Kattmann, U.; Komorek, M.; Parchmann, I. The Model of Educational Reconstruction. In Science Education Research and Practice in Europe; Jorde, D., Dillon, J., Eds.; Sense Publishers: Rotterdam, The Netherlands, 2012; pp. 13-37. ISBN 978-94-6091-900-8.

7. Leinhardt, G.; Ravi, A.K. Changing Historical Conceptions of History. In International Handbook of Research on Conceptual Change; Vosniadou, S., Ed.; Routledge: New York, NY, USA, 2008; pp. 328-341. ISBN 978-0-8058-6044-3.

8. Voss, J.F.; Wiley, J. Expertise in History. In The Cambridge Handbook of Expertise and Expert Performance; Ericsson, K.A., Charness, N., Feltovich, P.J., Hoffman, R.R., Eds.; Cambridge University Press: Cambridge, UK, 2006; pp. 569-584. ISBN 978-0-511-81679-6.

9. Vosniadou, S.; Verschaffel, L. Extending the Conceptual Change Approach to Mathematics Learning and Teaching. Learn. Instr. 2004, 14, 445-451. [CrossRef]

10. Stofflett, R.T. The Accommodation of Science Pedagogical Knowledge: The Application of Conceptual Change Constructs to Teacher Education. J. Res. Sci. Teach. 1994, 31, 787-810. [CrossRef]

11. Hewson, P.W.; Tabachnick, B.R.; Zeichner, K.M.; Lemberger, J. Educating Prospective Teachers of Biology: Findings, Limitations, and Recommendations. Sci. Educ. 1999, 83, 373-384. [CrossRef]

12. Möller, K.; Kleickmann, T.; Jonen, A. Zur Veränderung des naturwissenschaftsbezogenen fachspezifischpädagogischen Wissens von Grundschullehrkräften durch Lehrerfortbildungen. In Lehrerkompetenzen für den Sachunterricht; Hartinger, A., Fölling-Albers, M., Eds.; Klinkhardt: Bad Heilbrunn, Germany, 2004; pp. 231-241. ISBN 978-3-7815-1325-9.

13. Hand, B.; Treagust, D.F. Teachers' Thoughts about Changing to Constructivist Teaching/Learning Approaches within Junior Secondary Science Classrooms. J. Educ. Teach. 1994, 20, 97-112. [CrossRef]

14. Gustafson, B.J.; Rowell, P.M. Elementary Preservice Teachers: Constructing Conceptions about Learning Science, Teaching Science and the Nature of Science. Int. J. Sci. Educ. 1995, 17, 589-605. [CrossRef] 
15. Kunter, M.; Klusmann, U.; Baumert, J.; Richter, D.; Voss, T.; Hachfeld, A. Professional Competence of Teachers: Effects on Instructional Quality and Student Development. J. Educ. Psychol. 2013, 105, 805-820. [CrossRef]

16. Shulman, L. Knowledge and Teaching: Foundations of the New Reform. Harvard Educ. Rev. 1987, 57, 1-23. [CrossRef]

17. Van Dijk, E.M.; Kattmann, U. A Research Model for the Study of Science Teachers' PCK and Improving Teacher Education. Teach. Teach. Educ. 2007, 23, 885-897. [CrossRef]

18. Fischler, H. Über den Einfluss von Unterrichtserfahrungen auf die Vorstellungen vom Lehren und Lernen bei Lehrerstudenten der Physik. Teil 1: Stand der Forschung sowie Ziele und Methoden der Untersuchung. ZfDN 2000, 6, 27-36.

19. Kunter, M.; Pohlmann, B. Lehrer. In Pädagogische Psychologie; Wild, E., Möller, J., Eds.; Springer: Heidelberg/Berlin, Germany, 2009; pp. 261-282. ISBN 978-3-540-88572-6.

20. Brand, M.; Markowitsch, H.J. Lernen Und Gedächtnis. PdN 2004, 7, 1-13.

21. Giffhorn, B. Das Lernen verstehen lernen. Unterricht Biologie 2005, 303, 12-17.

22. Zabel, J. Lernen Im Schlaf- Ein Unterrichtsmodell. Neurobiologie und Lernen 2004, 7, $21-27$.

23. Burkard, R.F.; Biological Sciences Curriculum Study; National Institute on Deafness and Other Communication Disorders (U.S.); National Institutes of Health (U.S.). How Your Brain Understands What Your Ear Hears; BSCS: Colorado Springs, CO, USA, 2003; ISBN 1-929614-10-1.

24. Grospietsch, F.; Mayer, J. Konzepte angehender Biologielehrkräfte zu Lernen und Gedächtnis. Neuromythen oder Neurowissenschaften? In Erkenntnisweg Biologiedidaktik 16; Krüger, D., Schmiemann, P., Möller, A., Dittmer, A., Retzlaff-Fürst, C., Eds.; 2018; pp. 9-23. Available online: http:/ / www.bcp.fu-berlin.de/biologie/ arbeitsgruppen/didaktik/Erkenntnisweg/2017/Beitrag1Grospietsch.pdf (accessed on 24 June 2018).

25. Organisation for Economic Co-operation and Development (OECD). Understanding the Brain: Towards a New Learning Science; Organisation for Economic Co-operation and Development: Paris, France, 2002.

26. Macdonald, K.; Germine, L.; Anderson, A.; Christodoulou, J.; McGrath, L.M. Dispelling the Myth: Training in Education or Neuroscience Decreases but Does Not Eliminate Beliefs in Neuromyths. Front. Psychol. 2017, 8, 1314:1-1314:16. [CrossRef] [PubMed]

27. Dekker, S.; Lee, N.C.; Howard-Jones, P.; Jolles, J. Neuromyths in Education: Prevalence and Predictors of Misconceptions among Teachers. Front. Psychol. 2012, 3, 429:1-429:8. [CrossRef] [PubMed]

28. Simmonds, A. How Neuroscience Is Affecting Education: Report of Teacher and Parent Survey. 2014. Available online: https:/ / wellcome.ac.uk/sites/default/files/wtp055240.pdf (accessed on 21 June 2018).

29. Rato, J.R.; Abreu, A.M.; Castro-Caldas, A. Neuromyths in Education: What Is Fact and What Is Fiction for Portuguese Teachers? Educ. Res. 2013, 55, 441-453. [CrossRef]

30. Deligiannidi, K.; Howard-Jones, P.A. The Neuroscience Literacy of Teachers in Greece. Procedia Soc. Behav. Sci. 2015, 174, 3909-3915. [CrossRef]

31. Tardif, E.; Doudin, P.-A.; Meylan, N. Neuromyths among Teachers and Student Teachers: Neuromyths. Mind Brain Educ. 2015, 9, 50-59. [CrossRef]

32. Ferrero, M.; Garaizar, P.; Vadillo, M.A. Neuromyths in Education: Prevalence among Spanish Teachers and an Exploration of Cross-Cultural Variation. Front. Hum. Neurosci. 2016, 10, 496:1-496:12. [CrossRef] [PubMed]

33. Pei, X.; Howard-Jones, P.A.; Zhang, S.; Liu, X.; Jin, Y. Teachers' Understanding about the Brain in East China. Procedia Soc. Behav. Sci. 2015, 174, 3681-3688. [CrossRef]

34. Karakus, O.; Howard-Jones, P.A.; Jay, T. Primary and Secondary School Teachers' Knowledge and Misconceptions about the Brain in Turkey. Procedia Soc. Behav. Sci. 2015, 174, 1933-1940. [CrossRef]

35. Bellert, A.; Graham, L. Neuromyths and Neurofacts: Information from Cognitive Neuroscience for Classroom and Learning Support Teachers. Spec. Educ. Perspect. 2013, 22, 7-20.

36. Bartoszeck, A.B.; Bartoszeck, F.K. Investigating Children's Conceptions of the Brain: First Steps. Int. J. Env. Sci. Ed. 2012, 7, 123-139.

37. Gleichgerrcht, E.; Lira Luttges, B.; Salvarezza, F.; Campos, A.L. Educational Neuromyths among Teachers in Latin America. Mind Brain Educ. 2015, 9, 170-178. [CrossRef]

38. Lethaby, C.; Harries, P. Learning Styles and Teacher Training: Are We Perpetuating Neuromyths? ELT J. 2016, 70, 16-27. [CrossRef] 
39. Howard-Jones, P.; Franey, L.; Mashmoushi, R.; Liao, Y.-C. The Neuroscience Literacy of Trainee Teachers. In Proceedings of the British Educational Research Association Annual Conference, University of Manchester, Oxford, UK, 2-5 September 2009.

40. Fuentes, A.; Risso, A. Evaluación de Conocimientos y Actitudes Sobre Neuromitos En Futuros/as Maestros/As. Revista de Estudios e Investigación en Psicología y Educación 2015, 6. [CrossRef]

41. Dündar, S.; Gündüz, N. Misconceptions Regarding the Brain: The Neuromyths of Preservice Teachers. Mind Brain Educ. 2016, 10, 212-232. [CrossRef]

42. Düvel, N.; Wolf, A.; Kopiez, R. Neuromyths in Music Education: Prevalence and Predictors of Misconceptions among Teachers and Students. Front. Psychol. 2017, 8, 629:1-629:13. [CrossRef] [PubMed]

43. Canbulat, T.; Kiriktas, H. Assessment of Educational Neuromyths among Teachers and Teacher Candidates. J. Educ. Learn. 2017, 6, 326-333. [CrossRef]

44. Kim, M.; Sankey, D. Philosophy, Neuroscience and Pre-Service Teachers' Beliefs in Neuromyths: A Call for Remedial Action. Educ. Philos. Theory 2017, 1-14. [CrossRef]

45. Papadatou-Pastou, M.; Haliou, E.; Vlachos, F. Brain Knowledge and the Prevalence of Neuromyths among Prospective Teachers in Greece. Front. Psychol. 2017, 8, 804:1-804:13. [CrossRef] [PubMed]

46. Howard-Jones, P.A. Neuroscience and Education: Myths and Messages. Nat. Rev. Neurosci. 2014, 15, 817-824. [CrossRef] [PubMed]

47. Stark, R. Conceptual Change: kognitiv oder situiert?: Conceptual Change: From a Cognitive or Situated Perspective? Zeitschrift für Pädagogische Psychologie 2003, 17, 133-144. [CrossRef]

48. Duit, R.; Treagust, D.F.; Widodo, A. Teaching Science for Conceptual Change: Theory and Practice. In International Handbook of Research on Conceptual Change; Vosniadou, S., Ed.; Educational Psychology Handbook Series; Routledge/Taylor \& Francis Group: New York, NY, USA, 2013; pp. 487-503. ISBN 978-0-415-89882.

49. DiSessa, A.A. A Bird's-Eye View of the "Pieces" vs. "Coherence" Controversy (from the "Pieces" Side of the Fence). In International Handbook of Research on Conceptual Change; Vosniadou, S., Ed.; Routledge/Taylor \& Francis Group: New York, NY, USA; London, UK, 2013; pp. 31-48. ISBN 978-0415898836.

50. Vosniadou, S. Conceptual Change in Learning and Instruction: The Framework Theory Approach. In International Handbook of Research on Conceptual Change; Vosniadou, S., Ed.; Routledge/Taylor \& Francis Group: New York, NY, USA; London, UK, 2013; pp. 11-30. ISBN 978-0415898836.

51. Chi, M.T.H. Two Kinds and Four Sub-Types of Misconceived Knowledge, Ways to Change It, and the Learning Outcomes. In International Handbook of Research on Conceptual Change; Vosniadou, S., Ed.; Routledge/Taylor \& Francis Group: New York, NY, USA; London, UK, 2013; pp. 49-70. ISBN 978-0415898836.

52. Caravita, S.; Halldén, O. Re-Framing the Problem of Conceptual Change. Learn. Instr. 1994, 4, 89-111. [CrossRef]

53. Säljö, R. Concepts, Cognition and Discourse. From Mental Structures to Discursive Tools. In New Perspectives on Conceptual Change; Schnotz, W., Vosniadou, S., Carretero, M., European Association for Research on Learning and Instruction, Eds.; Pergamon: Oxford, UK; New York, NY, USA, 1999; pp. 81-90. ISBN 978-0-08-043455-1.

54. Posner, G.J.; Strike, K.A.; Hewson, P.W.; Gertzog, W.A. Accommodation of a Scientific Conception: Toward a Theory of Conceptual Change. Sci. Educ. 1982, 66, 211-227. [CrossRef]

55. Chi, M.T.H.; Slotta, D.J.; De Leeuw, N. From Things to Processes: A Theory of Conceptual Change for Learning Science Concepts. Learn. Instr. 1994, 4, 27-43. [CrossRef]

56. Pintrich, P.R.; Marx, R.W.; Boyle, R.A. Beyond Cold Conceptual Change: The Role of Motivational Beliefs and Classroom Contextual Factors in the Process of Conceptual Change. Rev. Educ. Res. 1993, 63, 167-199. [CrossRef]

57. DiSessa, A.A. Why "Conceptual Ecology" Is a Good Idea. In Reconsidering Conceptual Change: Issues in Theory and Practice; Limón, M., Mason, L., Eds.; Kluwer Academic Publishers: Dordrecht, The Netherlands, 2002; pp. 29-60. ISBN 978-1-4020-0494-0.

58. Schnotz, W. Conceptual Change. In Handwörterbuch Pädagogische Psychologie, 3rd ed.; Schlüsselbegriffe, Ed.; Beltz PVU: Weinheim, Germany, 2006; pp. 77-82. ISBN 978-3-621-27585-9.

59. Wiesner, H. Physikunterricht-An Schülervorstellungen orientiert. PdN-Physik in der Schule 2008, 57, 4-5.

60. Woolfolk Hoy, A.; Davis, H.; Pape, S.J. Teacher Knowledge and Beliefs. In Handbook of Educational Psychology; Alexander, P.A., Winne, P.H., Eds.; Erlbaum: Mahwah, NJ, USA, 2006; pp. 715-737. ISBN 978-0-8058-4937-0. 
61. Pajares, M.F. Teachers' Beliefs and Educational Research: Cleaning Up a Messy Construct. Rev. Educ. Res. 1992, 62, 307-332. [CrossRef]

62. Brauer, H.; Balster, S.; Wilde, M. Lehr- und Lernvorstellungen künftig Lehrender zum Lernen von Schülerinnen und Schülern im Fach Biologie. ZfDN 2014, 20, 191-200. [CrossRef]

63. Langfeldt, H.-P.; Nieder, T. Subjektive Lerntheorien von Lehramtsstudierenden-Ein Forschungsprogramm zur Qualitätsverbesserung in der universitären Lehrerbildung. In PISA und die Konsequenzen für die Erziehungswissenschaftliche Forschung; Lenzen, D., Baumert, J., Watermann, R., Trautwein, U., Eds.; VS Verl. für Sozialwiss: Wiesbaden, Germany, 2004; pp. 159-170. ISBN 978-3-8100-4024-4.

64. Staub, F.C.; Stern, E. The Nature of Teachers' Pedagogical Content Beliefs Matters for Students' Achievement Gains: Quasi-Experimental Evidence from Elementary Mathematics. J. Educ. Psychol. 2002, 94, $344-355$. [CrossRef]

65. Clement, J. Students' Preconceptions in Introductory Mechanics. Am. J. Phys. 1982, 50, 66-71. [CrossRef]

66. Kagan, D.M. Implication of Research on Teacher Belief. Educ. Psychol. 1992, 27, 65-90. [CrossRef]

67. Muller, D.A.; Bewes, J.; Sharma, M.D.; Reimann, P. Saying the wrong thing: improving learning with multimedia by including misconceptions: Misconception-based multimedia instruction. J. Comput. Assis. Learn. 2007, 24, 144-155. [CrossRef]

68. Cakir, Ö.S.; Geban, Ö.; Yürük, N. Effectiveness of Conceptual Change Text-oriented Instruction on Students' Understanding of Cellular Respiration Concepts. Biochem. Mol. Biol. Educ. 2002, 30, 239-243. [CrossRef]

69. Wang, T.; Andre, T. Conceptual Change Text versus Traditional Text and Application Questions versus No Questions in Learning about Electricity. Contemp. Educ. Psychol. 1991, 16, 103-116. [CrossRef]

70. Carlsen, D.; Andre, T. Use of a Microcomputer Simulation and Conceptual Change Text to Overcome Student Preconceptions about Electric Circuits. J. Comput. Based Instr. 1992, 19, 105-109.

71. Hynd, C.R.; McWhorter, J.Y.; Phares, V.L.; Suttles, C.W. The role of instructional variables in conceptual change in high school physics topics. J. Res. Sci. Teach. 1994, 31, 933-946. [CrossRef]

72. Chambliss, M.J. The characteristics of well-designed science textbooks. In The Psychology of Science Text Comprehension; Otero, J., León, J.A., Graesser, A.C., Eds.; Lawrence Erlbaum Associates: Mahwah, NJ, USA, 2002; pp. 51-72. ISBN 978-0-8058-3874-9.

73. Beerenwinkel, A.; Parchmann, I.; Gräsel, C. Conceptual Change Texts in Chemistry Teaching: A Study on the Particle Model of Matter. Int. J. Sci. Math. Educ. 2011, 9, 1235-1259. [CrossRef]

74. Egbers, M.; Marohn, A. Konzeptwechseltexte-Eine Textart zur Veränderung von Schülervorstellungen. Chemkon 2013, 20, 119-126. [CrossRef]

75. Chambers, S.K.; Andre, T. Gender, prior knowledge, interest, and experience in electricity and conceptual change text manipulations in learning about direct current. J. Res. Sci. Teach. 1997, 34, 107-123. [CrossRef]

76. Grospietsch, F.; Mayer, J. Lernen mittels professionellem Konzeptwechsel in der Hochschuldidaktik. In Lehrerausbildung in Vernetzten Lernumgebungen; Meier, M., Ziepprecht, K., Mayer, J., Eds.; Waxmann: Münster, Germany, 2016.

77. Grospietsch, F.; Mayer, J. Professioneller Konzeptwechsel zum Thema Neuromythen in der universitären Lehramtsausbildung Biologie. In Lehrerausbildung in Vernetzten Lernumgebungen; Meier, M., Ziepprecht, K., Mayer, J., Eds.; Waxmann: Münster, Germany, 2018.

78. Meier, M.; Grospietsch, F.; Mayer, J. Vernetzung von Wissensfacetten professioneller Handlungskompetenz in hochschuldidaktischen Lehr-Lernsettings. In Projekte und Ergebnisse zur Vernetzung von Fachdidaktik, Fachwissenschaft und Bildungswissenschaften im Rahmen der Qualitätsoffensive Lehrerbildung; Borowski, A., Glowinski, I., Gillen, J., Schanze, S., von Meien, J., Eds.; Unpublished, in press.

79. Block, J.H.; Hazelip, K. Teachers' Beliefs and Belief Systems. In International Encyclopedia of Teaching and Teacher Education; Anderson, L.W., Ed.; Resources in Education; Pergamon: Oxford, UK; New York, NY, USA, 1995; pp. 25-28. ISBN 978-0-08-042304-3.

80. Wahl, D. Lernumgebungen Erfolgreich Gestalten: Vom Trägen Wissen zum Kompetenten Handeln; Klinkhardt: Bad-Heilbrunn, Germany, 2005; ISBN 978-3-7815-1404-1.

81. Kleickmann, T.; Zimmermann, F.; Köller, O.; Möller, J.; Hohenstein, F. Erfassung von Pädagogischem Und Psychologischem Wissen in Der Lehramtsausbildung: Entwicklung Eines Messinstruments. ZfPäd 2017, 1, 91-113. [CrossRef]

82. Seifert, A.; Hilligus, A.H.; Schaper, N. Entwicklung und Psychometrische Überprüfung eines Messinstruments zur Erfassung Pädagogischer Kompetenzen in der universitären Lehrerbildung. LbP 2009, 2, 82-103. 
83. Gimbel, K.; Ziepprecht, K.; Mayer, J. Überzeugungen angehender Lehrkräfte fachspezifisch und inhaltsspezifisch operationalisieren und erfassen. In Projekte und Ergebnisse zur Vernetzung von Fachdidaktik, Fachwissenschaft und Bildungswissenschaften im Rahmen der Qualitätsoffensive Lehrerbildung; Borowski, A., Glowinski, I., Gillen, J., Schanze, S., von Meien, J., Eds.; Unpublished, in press.

84. Dunlap, W.P.; Cortina, J.M.; Vaslow, J.B.; Burke, M.J. Meta-Analysis of Experiments with Matched Groups or Repeated Measures Designs. Psychol. Methods 1996, 1, 170-177. [CrossRef]

85. Bortz, J. Statistik für Sozialwissenschaftler, Springer-Lehrbuch, 5th completely revised and updated ed.; Springer: Berlin, Germany, 1999; ISBN 978-3-540-65088-1.

86. Rosenthal, R. Meta-Analytic Procedures for Social Research; SAGE Publications, Inc.: Thousand Oaks, CA, USA, 1991; ISBN 978-0-8039-4246-2.

87. Morris, S.B.; DeShon, R.P. Combining effect size estimates in meta-analysis with repeated measures and independent-groups designs. Psychol. Methods 2002, 7, 105-125. [CrossRef] [PubMed]

88. Zöfel, P. Statistik für Psychologen: im Klartext; Im Klartext; Pearson, Higher Education: München, Germany, 2003; ISBN 978-3-8273-7063-1.

89. Cohen, J. Statistical Power Analysis for the Behavioral Sciences, 2nd ed.; L. Erlbaum Associates: Hillsdale, NJ, USA, 1988; ISBN 978-0-8058-0283-2.

90. Mahler, D.; Großschedl, J.; Harms, U. Using doubly latent multilevel analysis to elucidate relationships between science teachers' professional knowledge and students' performance. Int. J. Sci. Educ. 2017, 39, 213-237. [CrossRef]

91. Großschedl, J.; Harms, U.; Kleickmann, T.; Glowinski, I. Preservice Biology Teachers' Professional Knowledge: Structure and Learning Opportunities. J. Sci. Teach. Educ. 2015, 26, 291-318. [CrossRef]

92. Großschedl, J.; Mahler, D.; Kleickmann, T.; Harms, U. Content-Related Knowledge of Biology Teachers from Secondary Schools: Structure and learning opportunities. Int. J. Sci. Educ. 2014, 36, 2335-2366. [CrossRef]

93. König, J.; Doll, J.; Buchholtz, N.; Förster, S.; Kaspar, K.; Rühl, A.-M.; Strauß, S.; Bremerich-Vos, A.; Fladung, I.; Kaiser, G. Pädagogisches Wissen versus fachdidaktisches Wissen?: Struktur des professionellen Wissens bei angehenden Deutsch-, Englisch- und Mathematiklehrkräften im Studium. ZfE 2018, 21, 1-38. [CrossRef]

94. Großschedl, J.; Neubrand, C.; Kirchner, A.; Oppermann, L.; Basel, N.; Gantner, S. Entwicklung und Validierung eines Testinstruments zur Erfassung des evolutionsbezogenen Professionswissens von Lehramtsstudierenden (ProWiE). ZfDN 2015, 21, 173-185. [CrossRef]

95. Kirschner, S.; Sczudlek, M.; Tepner, O.; Borowski, A.; Fischer, H.E.; Lenske, G.; Leutner, D.; Neuhaus, B.J.; Sumfleth, E.; Thillmann, H.; et al. Professionswissen in den Naturwissenschaften (ProwiN). In Entwicklung von Professionalität Pädagogischen Personals; Gräsel, C., Trempler, K., Eds.; Springer Fachmedien Wiesbaden: Wiesbaden, Germany, 2017; pp. 113-130. ISBN 978-3-658-07273-5.

96. Wild, K.-P. Lernstrategien im Studium: Strukturen und Bedingungen; Pädagogische Psychologie und Entwicklungspsychologie; Waxmann: Münster, Germany, 2000; ISBN 978-3-89325-791-1.

97. Helmke, A. Unterrichtsqualität und Lehrerprofessionalität. Diagnose, Evaluation und Verbesserung des Unterrichts; Klett-Kallmeyer: Seelze, Germany, 2014.

98. Schlichter, N. Lehrerüberzeugungen zum Lehren und Lernen. Ph.D. Thesis, Georg-August-Universität Göttingen, Göttingen, Germany, 3 December 2012.

99. Wagner, K.; Stark, R.; Daudbasic, J.; Klein, M.; Krause, U.-M.; Herzmann, P. Effektivität integrierter Lernumgebungen in der universitären Lehrerbildung-eine quasiexperimentelle Feldstudie. J. Educ. Res. Online 2013, 5, 115-140.

100. Buelens, H.; Clement, M.; Clarebout, G. University Assistants' Conceptions of Knowledge, Learning and Instruction. Res. Educ. 2002, 67, 44-57. [CrossRef]

101. Weisberg, D.S.; Keil, F.C.; Goodstein, J.; Rawson, E.; Gray, J.R. The Seductive Allure of Neuroscience Explanations. J. Cogn. Neurosci. 2008, 20, 470-477. [CrossRef] [PubMed]

102. Guzzetti, B.J.; Snyder, T.E.; Glass, G.V.; Gamas, W.S. Promoting Conceptual Change in Science: A Comparative Meta-Analysis of Instructional Interventions from Reading Education and Science Education. Read. Res. Q. 1993, 28, 116-159. [CrossRef]

103. Kowalski, P.; Taylor, A.K. The Effect of Refuting Misconceptions in the Introductory Psychology Class. Teach. Psychol. 2009, 36, 153-159. [CrossRef]

104. Kowalski, P.; Taylor, A.K. Effectiveness of refutational teaching for high- and low-achieving students. J. Scholarsh. Teach. Learn. 2011, 11, 79-90. 
105. Howard-Jones, P. Introducing Neuroeducational Research: Neuroscience, Education and the Brain from Contexts to Practice; Routledge: London, UK; New York, NY, USA, 2010; ISBN 978-0-415-47200-5.

106. Goswami, U. Neuroscience, education and special education. Br. J. Spec. Educ. 2004, 31, 175-183. [CrossRef]

107. Ansari, D.; Coch, D. Bridges over troubled waters: education and cognitive neuroscience. Trends Cogn. Sci. 2006, 10, 146-151. [CrossRef] [PubMed]

108. Fischer, K.W.; Goswami, U.; Geake, J.; the Task Force on the Future of Educational Neuroscience. The Future of Educational Neuroscience. Mind Brain Educ. 2010, 4, 68-80. [CrossRef]

109. Lindell, A.K.; Kidd, E. Why Right-Brain Teaching is Half-Witted: A Critique of the Misapplication of Neuroscience to Education. Mind Brain Educ. 2011, 5, 121-127. [CrossRef]

110. Royal Society (Great Britain). Brain Waves Module 2: Neuroscience: Implications for Education and Lifelong Learning; Royal Society: London, UK, 2011; ISBN 978-0-85403-880-0.

111. Goswami, U. Neuroscience and education: from research to practice? Nat. Rev. Neurosci. 2006, 7, 406-413. [CrossRef] [PubMed]

112. Petitto, L.-A.; Dunbar, K. New Findings from Educational Neuroscience on Bilingual Brains, Scientific Brains, and the Educated Mind. In Proceedings of the Conference on Building Usable Knowledge of Mind, Brain, and Education, Harvard Graduate School of Education, Cambridge, MA, USA, 6-8 October 2004.

113. Newton, P.M.; Miah, M. Evidence-Based Higher Education-Is the Learning Styles 'Myth' Important? Front. Psychol. 2017, 8, 444:1-444:9. [CrossRef] [PubMed]

114. Uzuntiryaki, E.; Geban, Ö. Effect of Conceptual Change Approach Accompanied with Concept Mapping on Understanding of Solution Concepts. Instr. Sci. 2005, 33, 311-339. [CrossRef]

115. Beerenwinkel, A.; Parchmann, I. Ansätze Zur Berücksichtigung von Lernervorstellungen in Lehrtexten Und Schulbüchern Zum Kontextorientierten Lernen. BzL 2010, 28, 62-72.

(C) 2018 by the authors. Licensee MDPI, Basel, Switzerland. This article is an open access article distributed under the terms and conditions of the Creative Commons Attribution (CC BY) license (http:/ / creativecommons.org/licenses/by/4.0/). 